\title{
Prevention of Insider Trading and Corporate Good Governance
}

\author{
Sandeep Parekh \\ spparekh@iimahd.ernet.in \\ Working Paper \\ January 2003
}




\title{
Prevention of Insider Trading and Corporate Good Governance
}

Sandeep Parekh

Visiting Faculty

spparekh@iimahd.ernet.in

\begin{abstract}
With the discovery of massive frauds in the Indian and International capital markets, regulators and legislatures have increasingly turned towards making corporate governance standards mandatory and have attached penalties to violation of these 'corporate governance' 'guidelines'. This paper questions the necessity for associating corporate governance in the insider trading context with penal provisions in India. It makes suggestions for the removal of these penalties and instead let the markets decide whether to penalise companies which do not have these process oriented safeguards in place. The paper also recommends introduction of certain substantive and procedural regulations/standards for reduction of the incidence of insider trading in companies.
\end{abstract}

\section{INTRODUCTION}

\section{Insider Trading}

Insider trading is one of the most violent crimes on the faith of fair dealing in a capital market. The scope and stringency of the violation and penalties differ wildly from country to country. Trading by an insider of a company in the shares of a company is not per se a violation of law. For instance a person (an investigative journalist for example may interview an insider and thus become one) may come across insider information by his perseverance in uncovering a corporate fraud and disclose the fraud. A person can create inside information by his future actions, for instance a future tender offer bidder knows that the price of the target company will go up by his actions. In fact trading by insiders, including directors, 
officers and employees of the company in the shares of their own company is a positive feature which companies should encourage because it aligns its interests with those of the insiders. What is prohibited is the trading by an insider in breach of a duty of trust or confidence in the stock of a company on the basis of non public information to the exclusion of others. Insider trading violations may also include "tipping" such information and securities trading by the person "tipped".

If insider trading is allowed unchecked in the capital markets, persons with insider information will have a consistent edge in trades executed with such information and those without the information will be consistent losers on the market. The latter category of people, which includes the vast majority of investors, would slowly realize the loser game they are playing in this 'market for lemons' and would believe that all transactions are thus biased against them. Slowly the typical investor would desert the market, retarding or destroying important functions of the stock market like capital formation.

\section{Efficient Capital Market Hypothesis}

In fact in an efficient market, even one share traded on insider trading would violate the integrity of the markets. According to the Efficient Capital Market Hypothesis, a buyer of just one share impacts not merely the counterparty seller, but the entire market. The buyer's purchase order drives up demand of the shares and affects all contemporaneous traders on the sell side of the transaction. The US Supreme Court has used Eugene Fama's ${ }^{1}$ theory of Efficient Capital Market Hypothesis in Basic v. Levinson ${ }^{2}$ to come to the conclusion that the requirement of reliance in a fraud action in the securities markets is highly diluted ${ }^{3}$ because $^{-1}$ information is converted into price in today's anonymous markets ${ }^{4}$. Thus anyone who relies on the price of a security, need not show the common law requirement of reliance in a suit for damages based on fraud. The court said

"The modern securities markets, literally involving millions of shares changing hands daily, differ from the face-to-face transactions contemplated by early fraud cases, and

\footnotetext{
${ }^{1}$ Efficient Capital Markets. Journal of Finance, 25, 383-417 2108 S.Ct. 978

${ }^{3}$ More accurately, the judgment creates a rebuttable presumption of reliance. Thus the onus is on the defendant to show that in fact the plaintiff thought otherwise.

4 See also "Use of Modern Finance Theory in Securities Fraud Cases Involving Actively Traded Securities", 38

Bus.Law. 1, 4, n. 9 (1982)
} 
our understanding of Rule $10 \mathrm{~b}-5$ 's reliance requirement must encompass these differences."

In face-to-face transactions, the inquiry into an investor's reliance upon information is into the subjective pricing of that information by that investor. With the presence of a market, the market is interposed between seller and buyer and, ideally, transmits information to the investor in the processed form of a market price. Thus the market is performing a substantial part of the valuation process performed by the investor in a face-to-face transaction. The market is acting as the unpaid agent of the investor, informing him that given all the information available to it, the value of the stock is worth the market price."

Insider trading, being a species of frauds, has also seen such economic rationale making inroads into legal theories of damages and injunctive action. In any case the point being, even one insider violates the integrity of the market and not just the confidence of the counterparty to his trade.

\section{Levels of prohibition in other countries}

There have been several arguments ${ }^{5}$ in favour of allowing insider trading for purposes of efficiency and as a means to reward management and directors of a company. ${ }^{6}$ Certain countries, do not have a prohibition on insider trading. Certain countries, like the US, do not automatically prohibit trading on the basis of mere possession of inside information. There must be a fiduciary relationship of the insider with the company before the person can be sanctioned.

\section{Means of controlling insider trading}

Criminal: One way of dealing with insider trading is by passing regulations prohibiting such trades, making them penal and enforcing criminal actions against violators. As any penal provision, this is supposed to deter others from violating the regulations. However,

\footnotetext{
${ }^{5}$ See The economic structure of corporate law, Easterbrook and Fischel, p. 253. This line of theory is generally espoused by the Chicago school of economics.

${ }^{6}$ Other arguments in favour of allowing insider trading are that in light of trading volume insider trading has no material impact on other investors. Besides it is argued that victims are selected randomly because of the now faceless market. See. Henry G. Manne, Insider Trading and the Stock Market (1966).
} 
experience has shown us that this method provides only a small amount of relief even in more heavily regulated countries.

Thus the threat of a jail sentence for the offender under S.24 of the SEBI Act is more of a paper tiger. Though the jail sentence may look good on the statute, history bears out the difficulty in enforcing criminal prosecution against an economic offender. The burden of proof of proving a criminal charge is so onerous, the requirement of intent so strict, and the courts procedures so long and 'due' that conviction is an exceptional exception. For instance the only case of insider trading prosecuted by Dutch authorities in ten years failed on lack of proof. The Securities and Exchange Commission of the United States brought 47 cases of insider trading in the year $2001^{7}$ of which only 4 were referred to the Department of Justice for criminal action.

With a conviction rate of less than $3 \%$ in India, SEBI should really concentrate on efforts to economically paralyze insider traders instead of the more high profile and far less successful criminal sanctions. The not so recent action against the directors of Hindustan Lever Limited is a case in point. Two years after a case in their hands, the regulator is now getting the case to start criminally.

Civil and administrative penalties: Civil monetary penalties and issue of various administrative actions like bar from the industry without going to courts is a more effective remedy and with the enhanced powers granted to the regulator to impose penalties of 25 crores or three times the gain made, an economic harm can more easily be inflicted and deterrence more effectively administered. Unfortunately the wordings of the civil monetary penalties are drafted in such a poor manner that, the penalties are certain to be struck down (or diluted) as unconstitutional ${ }^{8}$.

A recent US case is illustrative of a typical civil penalty charged by the Securities and Exchange Commission. In SEC v. Steve Madden, the Commission filed a settled injunctive action against shoe designer Steve Madden alleging that he engaged in insider trading. The complaint alleged that after Madden learned from the criminal authorities that he was the

\footnotetext{
${ }^{7}$ SEC Annual Report, 2001

${ }^{8}$ The penalty provides for the higher of three times the gain made or 25 crores. Effectively, that imposes a minimum penalty of 25 crores on an insider trader.
} 
target of a criminal investigation and would be indicted or otherwise charged for securities fraud, he sold 100,000 shares of common stock in his company, Steven Madden Ltd. Madden sold this stock without disclosing to the public the information he had learned regarding the criminal investigation. After Madden was arrested, the company's stock price sank and Madden avoided losses of $\$ 784,000$. Madden consented to an order of permanent injunction and agreed to disgorge $\$ 784,000$ of illegally avoided losses, plus prejudgment interest, and to pay $\$ 784,000$ in civil penalties.

Prophylactics: The third way of attacking the problem is by encouraging the companies to practice self regulation and taking prophylactic action. This is inherently connected to the field of corporate governance. It is a means by which the company signals to the market that effective self regulation is in place and that investors are safe to invest in their securities. In addition to prohibiting inappropriate actions (which might not necessarily be prohibited), self regulation is also considered an effective means of creating shareholder value. Companies can always regulate their directors/officers beyond what is prohibited by the law.

\section{Corporate Governance}

Corporate governance thus is a means of self governance by companies whereby a company increases its 'firm value' by higher and qualitatively superior disclosure as well as more responsible action. It must be distinguished from regulations which are imposed by the law and which mandate behaviour at the risk of penalty.

\section{INSIDER TRADING}

\section{Definitions}

Without getting into the details, let us see briefly, what amounts to insider trading in India. According to the SEBI regulations on Prohibition of Insider Trading, ("the

\section{Regulations"):}

(e) "insider" means any person who, is or was connected with the company or is deemed to have been connected with the company, and who is reasonably expected to have access, connection, to unpublished price sensitive information in respect of securities of a company, or who has received or has had access to such unpublished price sensitive information; 
'price sensitive information' means any information which relates directly or indirectly to a company and which if published is likely to materially affect the price of securities of company;

\section{The Prohibition}

The express terms of the prohibition as contained in the Regulations is as follows:

3. No insider shall -

(i) either on his own behalf or on behalf of any other person, deal in securities of a company listed on any stock exchange when in possession of any unpublished price sensitive information; or

(ii) Communicate, counsel or procure, directly or indirectly, any unpublished price sensitive information to any person who while in possession of such unpublished price sensitive information shall not deal in securities.

Provided that nothing contained above shall be applicable to any communication required in the ordinary course of business or profession or employment or under any law.

3A. No company shall deal in the securities of another company or associate of that other company while in possession of any unpublished price sensitive information.

\section{Ingredients of violation}

The insider trading law of India is better codified than many of the western countries' laws, particularly the American law which has primarily been developed by case law and is quite unsettled in various respects (in part because the American legislature refuses to define insider trading). The American case law, which nonetheless is highly developed, is based on the general antifraud provisions of the Securities and Exchange Act $^{9}$

For the violation in India, several requirements are made by the regulations. First, the necessity of being an insider (which now specifically includes a company). Second, the

\footnotetext{
${ }^{9}$ The ubiquitous Rule 10b-5 of the regulations passed under the Act which prohibits fraud in connection with the purchase and sale of securities.
} 
possession of material unpublished price sensitive inside information. And lastly, the factum of dealing (there is another prohibition against disclosing such information) in securities.

An Insider is any person who by virtue of a duty owed to the company is expected to have (or has had) access to unpublished price sensitive information. Just by being privy to price sensitive non public information a person does not ipso facto become an insider. Thus a taxi driver, who has no connection with the company and overhears two directors discussing unpublished price sensitive information would not fall under the proscriptions of the Act. Every person who chances across inside information is not liable under the regulations. The insider trading regulations are not hypothesized over 'parity of information' theory. To draw an analogy, a person finds a gold coin lying on the road, and appropriates it for his benefit would hardly seem a crime punishable as would a fiduciary who is entrusted with a gold coin and who misappropriates it. A law which penalizes people based on a parity of information would be unnecessarily unfair and courts must guard against too broad an interpretation of the regulations.

The possession of material inside information raises the question - what is material and what is an inside unpublished price sensitive fact. What is material is a question of fact and will be depend on a balancing of both the indicated probability that the event will occur and the anticipated magnitude of the event in light of the totality of the company activity. ${ }^{10}$ Unusual trading by insiders could be a good indicator of materiality. Inside unpublished price sensitive fact is inside information which only a select few persons know because of their closeness to the company and which has not been publicly circulated. When does information enter the public domain? Probably not for at least a few hours after it is intimated to the public (via the stock exchange or the company's website). It is not within the scope of the paper to discuss what does and what doesn't constitute insider trading. Instead this paper focuses on the corporate governance guidelines, discusses their efficacy and questions their betrothal with the penal and criminal sanctions of the regulations.

\section{GOOD GOVERNANCE}

\section{Prophylactics and corporate good governance}

\footnotetext{
${ }^{10}$ TSC Industries v. Northway 426 US 438.
} 
The 2002 amendments to the Regulations provide extensive suggestions and also extensive regulations couched in the language of corporate good governance. Most of the good governance provisions are provided for as mandatory provisions.

Briefly, the good governance regulations provide for:

a) Officer, director and substantial shareholder to disclose their holding on certain events or at certain intervals.

b) Appointment of a compliance officer.

c) Setting forth policies and procedure to restrict the possibility of abuse of insider trading.

d) Monitoring and pre-clearance of trades by the designated persons.

e) Restrict trading by such insiders within a certain period of time i.e. before corporate announcements, buybacks etc. are made.

f) The company has to convey all the significant insider activity and corporate disclosure in a uniform publicly accessible means to the public - and to the stock exchange.

g) Chinese walls within a firm to prevent one part of the firm which deals in sensitive information from going to other parts of the firm which have an inherent conflict of interest with such other parts.

h) Minimum holding period of securities by insiders.

i) No selective disclosure to analysts. Wide dissemination of information.

\section{Sarbanes-Oxley Act}

The US legislature, witness to an unending line of scandals, recently passed amendments to the securities/disclosure laws of the country - in effect codifying into law several corporate governance suggestions previously made. The Sarbanes-Oxley Act of 2002 requires:

- directors, executive officers and large shareholders of public issuers to report transactions in the issuer's equity securities within two business days of a transaction.

- pre-clearance procedures for transactions in the issuer's equity securities;

- the responsibilities the company will take for completing filings;

- the requirement (or encouragement) to use a specified broker for transactions in the issuer's securities, or the certifications required from brokers if no specific broker is required; 
- the applicability of the rules to persons with business or family relations to the insider; and

- sanctions for failure to make timely filings.

We will see in the Indian context several of the good governance regulations for their relevance and their reason to exist on the statute and further whether they need to be divorced from the mandatory/penal consequences of the regulations.

\section{A. Officer, director and substantial shareholder to disclose their holding on certain events or at certain intervals.}

There should be some coordination between the requirement of reporting at the $5 \%$ level with the requirements of the takeover code. In fact the takeover reporting is broader in some respects since it mandates reporting by any person over certain thresholds and also requires reporting by a group - a concept not introduced in these regulations. However, the insider trading regulations provide for disclosure of smaller amounts and even provide for disclosure on selling shares (something which the takeover code does not mandate). It is suggested that a purchase disclosure made under either regulations (with the same or higher level of disclosure) should be deemed to be good disclosure under the other. Additionally, this author suggests the introduction of short swing profits.

Short Swing' profits: There should be a regulation introduced in the Insider Trading regulations which compels an insider to disgorge or turn in profits made by insiders to the company for any transaction in equity based securities in the company's securities (including it's parents or subsidiary's shares) if both the buy and sell side of the transaction is entered into within six months of the other.

Such a liability should be imposed without any necessity for guilt or wrongfulness. This would be a provision which would get automatically attracted as soon as two things are established. First, the fact of being a designated insider. And second, the fact that the same securities were bought and sold within six months of each other. Such a regulation would be relatively easy to administer, since an intent of the person is immaterial. Merely the fact of the trade is sufficient to take action. Thus the appearance of impropriety is removed from the markets.

\section{B. Restrict trading by insiders within a certain period of time i.e. before corporate announcements, buybacks etc. are made.}


Unfortunately, the wordings of the regulations are so broad, that it would chill trading in sometimes rather large windows. The regulation should not asphyxiate trading by insiders. As we have seen before trading by insiders and employees aligns their interests with those of the company and should be encouraged if there is no improper behaviour. Let us study the restriction for its scope.

\subsection{Trading window}

3.2.1 The company shall specify a trading period, to be called "Trading Window", for trading in the company's securities. The trading window shall be closed during the time the information referred to in para 3.2.3 is unpublished.

3.2.2 When the trading window is closed, the employees / directors shall not trade in the company's securities in such period.

3.2.3 The trading window shall be, inter alia, closed at the time of:-

(a) Declaration of Financial results (quarterly, half-yearly and annual)

(b) Declaration of dividends (interim and final)

(c) Issue of securities by way of public/ rights/bonus etc.

(d) Any major expansion plans or execution of new projects

(e) Amalgamation, mergers, takeovers and buy-back

(f) Disposal of whole or substantially whole of the undertaking

(g) Any changes in policies, plans or operations of the company

Issuance of bonus/rights shares has no real effect on the price of the security and therefore there is no need to have a restricted window for that purpose. (d) to (g) are too broad and could cause unnecessary problems. To give an example, a company makes a large gas find, in one grid. It does not want to disclose that fact so that it can buy the neighbouring grids at a bargain price. It therefore, for a valid business purpose keeps the find a secret for six months. Even though the directors who know about the find would be expressly prohibited from trading in the securities under the substantive provisions of the regulations, all employees (who do not know) too would be barred from trading for six months in the 
shares of the company. This is obviously not an unusual hypothetical. An auto company comes out with secretive plans for introducing 'new age' models almost every month. Such companies would never allow employees to trade in their shares because there is a closed window for any 'execution of new projects'. Let me clarify, that this does not in any way effect the substantive provisions which restrict insider trading - which of course is prohibited.

\section{Pre clearance of trades}

Certain provisions are made for clearing of trades if certain officers/employees engage in shares of their own company. To cite from Schedule I, Part A.

3.3.1 All directors/officers /designated employees of the company who intend to deal in the securities of the company (above a minimum threshold limit to be decided by the company) should pre-clear the transactions as per the pre-dealing procedure as described hereunder.

3.3.2 An application may be made in such form as the company may notify in this regard, to the Compliance officer indicating the estimated number of securities that the designated employee/ officer/ director intends to deal in, the details as to the depository with which he has a security account, the details as to the securities in such depository mode and such other details as may be required by any rule made by the company in this behalf.

\section{$* * *$}

4.1 All directors/officers/designated employees shall execute their order in respect of securities of the company within one week after the approval of pre-clearance is given. If the order is not executed within one week after the approval is given the employee/ director must pre clear the transaction again.

4.2 All directors/officers /designated employees shall hold their investments in securities for a minimum period of 30 days in order to be considered as being held for investment purposes. The holding period shall also apply to subscription in the primary market (IPOs). In the case of IPOs, the holding period would commence when the securities are actually allotted. 
Once securities are pre-cleared, there is no necessity of prescribing just one week for the trades to occur. This would expose the employees / officers to unnecessary market risk. Personal experience from the market seems to suggest that it is not uncommon in large institutions for officers to get their approval for trading after weeks from the date of application. Given a one week window to execute their orders would penalize employees with market timing risk while trading in their own company's stock. The company should be free to determine their own methodology and the window permitting execution of trade should certainly be restrictive regarding the quantity and the time frame should be far less material.

Regarding 4.2, a suggestion is already made for very senior officers (CEO, CFO, CIO, Company Secretary etc.) to come under the short swing rule. The other employees should be subject to a holding period and it should be specified that if they violate the term - they would need to disgorge any profits made in the period. Even absent mens rea, such a strict liability would still pass muster in a court of law because it is not truly penal in nature - more remedial and process oriented.

\section{Reporting of 'process' to CEO/MD}

There is clause which requires the $\mathrm{CEO} / \mathrm{MD}$ to consider all insider trades and accompanying documents.

5.3 The Compliance officer shall place before the Managing Director / Chief Executive Officer or a committee specified by the company, on a monthly basis all the details of the dealing in the securities by employees / director / officer of the company and the accompanying documents that such persons had executed under the pre-dealing procedure as envisaged in this code.

This kind of time for such a routine process by an MD is wasteful and unworkable - it is a totally unworkable clause for large companies and such micromanagement should not be part of corporate governance, leave alone regulations. This provision ought to be scrapped.

\section{Other entities having access to inside information}

Intermediaries in the capital markets like underwriters, lawyers, auditors are also required to comply with Part B of the first Schedule. The regulation of these other entities is overworked and overregulated at times and operationally impossible at other times. For instance having a 
compliance officer who inspects insider trades and grants pre-clearance for trades of securities of employees is absolutely uncalled for. To give an example practically every law firm advices listed companies. To have a compliance officer in every firm and monitoring of trades by each employee is completely unworkable - and even partial compliance will never happen. The fact that it is coupled with penalties of 10 years in jail, suspension, fines etc. should create a powerful argument for removal of these 'corporate governance' penalties for non corporates and in particular because adequate remedies are in place for actual insider trading. Certain other provisions are made for the intermediaries which need to be relooked at.

\section{E. Confidential Files}

"Files containing confidential information shall be kept secure. Computer files must have adequate security of login and pass word etc."

To mandate passwords/logins for securing confidential files is nonsensical, to say the least. It would create workings of entire organizations which are built on sharing information of confidential files unworkable. To again use the law firm example, if confidential files are not shared effectively between colleagues, effectively assisting a client may not be possible. It should be the discretion of the company/firm to bar access to such information as it sees fit. Such micromanagement should be frowned upon.

\section{OTHER RECOMMENDATIONS}

\section{Some possible additions to the regulations}

There are a few further provisions the Indian legislature/regulator should consider adding to the existing framework of regulations to reduce the occurrence of insider trading.

\section{Designated or qualified brokers.}

To facilitate compliance with the new reporting of transactions, issuers should either designate a single broker through whom all transactions in issuer stock by insiders must be completed or require insiders to use only brokers who will agree to the procedures set out by the company. A designated broker can help ensure compliance with the company's preclearance procedures and reporting obligations by monitoring all transactions and reporting them promptly to the issuer. If designating a single broker is not feasible, issuers should require insiders to obtain a certification from their broker that the broker will: 
- Verify with the issuer that each transaction entered on behalf of the insider was precleared; and

- Report immediately to the issuer the details of each of the insider's transactions in the issuer's securities.

\section{Derivatives amendments}

Parts of the regulations refer to 'shares' for the purpose of proscription while they should prohibit "securities" trading. For instance, one could, using derivatives, economically sell the shares without physically trading in those shares. ${ }^{11}$ Similarly, one can easily create synthetic securities with the same economic impact as an equity share of a company. By reclassifying shares into securities, one can eliminate the problem because securities are defined to include equity, quasi-equity, derivatives and any combination of the three. Pure debt instruments can be excluded specifically from the regulations.

Similarly, under Regulation 13 the disclosure requirements should refer to not merely a 5\% stake in the equity but also to a minimum stake in derivatives of the company's securities. The minimum can be a rupee amount of the market value of the derivative (since calculating $5 \%$ of the derivatives market is neither possible and if possible not meaningful)

\section{Civil private cause of action by contemporaneous traders}

People trading in the market contemporaneously - not just the regulator or the counterparties $^{12}$ to the insider should also have specific powers to rescind trades and charge damages to the insiders during the period when they traded. This will provide a broader remedy and will have many people exerting an economic pressure on the violator to make his trades unviable.

\section{Proactive Stock Exchanges}

The stock exchanges should take up at least a substantial burden of filing action against persons violating the regulations. Since the Rules and regulations of the stock exchanges are considered 'enactment', and court judgments ${ }^{13}$ have found exchange regulations to have the force of law - they could easily enforce the requirements of the listing terms or the rules and

\footnotetext{
${ }^{11}$ By selling futures in the derivatives market of the exchange.

${ }^{12}$ See the Efficient Capital Market Hypothesis above.

${ }^{13}$ See Vinay Bubna V. Stock Exchange, Bombay, 1999 (6) SCC 215
} 
regulations by seeking civil action in courts against persons or companies who violate such regulations. The exchanges should also better coordinate monitoring and surveillance of listed companies to track unusual activity in the stock of a company across markets for traces of insider dealings or manipulation.

\section{Recission}

One author has suggested that a contract of sale or purchase by an insider be declared void by the counterparty to a trade under the Indian Contract Act (this is besides the powers SEBI has to annul the trade under Regulation 11). Though legally feasible, it raises impossible burdens in today's virtually anonymous capital markets. For instance if an investor had bought 100 shares of the company during the period when the insider trading took place, it would be difficult to determine the counterparty to the insider. And in any case even if the counterparty to the trade is identified, the insider has not only hurt his trade counterparty but also the market as a whole. ${ }^{14}$ By buying (or selling) shares the insider would have raised (or lowered) the price of the shares so bought (or sold) and thus would affect the rights of every person who bought or sold contemporaneously.

\section{Tippee liability}

The regulations prohibit persons from tipping people about inside information by insiders i.e. the tipper. However, there seems to be no liability for a person who improperly receives a tip i.e. a tippee from trading. There is a vague prohibition against 'procurement' of information. However, it does not clearly prohibit a tippee from trading.

\section{Bounty system}

Section 21A(e) of the American Securities Exchange Act of 1934 authorizes the Securities and Exchange Commission to award a bounty to a person who provides information leading to the recovery of a civil penalty from an insider trader, from a person who "tipped" information to an insider trader, or from a person who directly or indirectly controlled an insider trader. This could be a useful addition to cracking into new cases of insider activity.

\section{The mystery penal clause}

\footnotetext{
${ }^{14}$ See Basic v. Levinson 485 US 224, above.
} 
In the schedule clause 7.1 penalises violation of the regulations and whistle blowing duties of senior officers. It is not clear whether the 'corporate governance' schedule is included in the duty to report a violation i.e. does it include a procedural violation as well. However, a look at Section 14 clears all doubts that one can go to jail for 10 years for violating simple or minor process oriented details.

14. (1) A person who violates provisions of regulation 12 shall be liable for action under Section 11 or $11 \mathrm{~B}$ and/or Section 24 of the Act.

This in a country where the penalty for rape could be as low as 7 years. Maybe, this is overstating the case, because a minor violation would not really be referred criminally. But then, why not make the entire Schedule optional. Let companies make a standardized disclosure in their annual report as to how much of the Schedule they are in compliance with and what they are not.

\section{Conclusion.}

The core of securities regulations is the implementation of the purpose that all investors should have equal access to the rewards of participation in securities transactions. In other words all members of the investing public should be subject to identical market risks. Inequities based upon unequal access to knowledge should not be shrugged off as inevitable in our way of life. It is therefore important for there to be markets free from all types of fraud and in particular insider trading which disenchants the common investor from the workings of the markets as if he is being invited to play a game of crap with loaded dice.

Unfortunately with the unearthing of large frauds, even though India is not unique in this, the concept of corporate good governance has been lost in the war cry for blood. And as a result, the government has gotten into overregulation and micromanagement by converting good governance into statutory provisions. We tend to forget that fraudulent action cannot be

stamped out by micromanagement, it can only be reduced by effective enforcement of the laws which should prohibit obvious illegalities.

It should not be forgotten that what is sought to be caught is crime and treating all insiders as inherently tending towards a presumption of unfair dealing should be avoided. Standards of corporate governance should be left at the helm of the managers of the company. The regulator should specify in the Schedule to the regulations a list of optional procedure for 
limiting the possibilities of insider trading. What should be mandated instead should be a statement in the annual report of the degree of compliance with the standards of set forth in the Schedule. Thus companies which do not follow corporate governance guidelines in substance would be penalized by its shareholders. An author has also suggested introduction of corporate governance ratings, similar to debt ratings which would pressure management to comply with such measures. This could be the missing link providing a simple number which can be appreciated and understood by the masses and would indicate the processes a company has put in place for the benefit of their non-insider shareholders.

Any comments may be addressed to

Sandeep Parekh

P.H. Parekh \& Co.

sandeep.parekh@phparekh.com or spparekh@iimahd.ernet.in

or by telephone at (91) (11) 23311282 